\title{
COMPARISON OF SMALL MAMMAL PREVALENCE OF Leishmania (Leishmania) mexicana IN FIVE FOCI OF CUTANEOUS LEISHMANIASIS IN THE STATE OF CAMPECHE, MEXICO
}

\author{
N.R. VAN WYNSBERGHE, S.B. CANTO-LARA, E.I. SOSA-BIBIANO, N.A. RIVERO-CÁRDENAS \& F.J. ANDRADE-NARVÁEZ
}

\begin{abstract}
SUMMARY
In the Yucatan Peninsula of Mexico, 95\% of the human cases of Cutaneous Leishmaniasis are caused by Leishmania (Leishmania) mexicana with an incidence rate of 5.08 per 100,000 inhabitants. Transmission is limited to the winter months (November to March). One study on wild rodents has incriminated Ototylomys phyllotis and Peromyscus yucatanicus as primary reservoirs of $L$. (L.) mexicana in the focus of La Libertad, Campeche. In the present study, the prevalence of both infection and disease caused by $L$. ( $L$.) mexicana in small terrestrial mammals were documented during five transmission seasons (1994-2004) in five foci of Leishmaniasis in the state of Campeche. Foci separated by only $100 \mathrm{~km}$, with similar relative abundances of small mammals, were found to differ significantly in their prevalence of both symptoms and infection. Transmission rates and reservoir species seemed to change in space as well as in time which limited the implementation of effective control measures of the disease even in a small endemic area such as the south of the Yucatan Peninsula.
\end{abstract}

KEYWORDS: Cutaneous Leishmaniasis; Leishmania (Leishmania) mexicana; Mammals, Prevalence, Mexico.

\section{INTRODUCTION}

Leishmaniasis is a serious world-wide problem with a DisabilityAdjusted Life Years (DALY) lost calculated at close to 2.4 million, with 1 to 1.5 million cases of Cutaneous Leishmaniasis (CL), and 350 million persons at risk $^{19}$. Among the fifteen well-recognized Leishmania species known to cause diseases in humans, thirteen have a zoonotic nature ${ }^{25}$.

In the Yucatan Peninsula of Mexico, Cutaneous Leishmaniasis (CL) has been observed to be an occupational disease of gum collectors ${ }^{12}$. The main risk-factor was spending nocturnal periods in the forest $t^{4}$. Nowadays, the number of gum-collectors has greatly diminished, following the use of artificial gum in the chewing-gum industry ${ }^{35}$ however, with the increase of military troop maneuvers, soldiers became another high-risk group ${ }^{6}$. However, an increase in the number of patients showing CL has been observed recently, likely due to the human colonization of large areas of previously untouched forests ${ }^{46}$. The government has attempted to relocate these people in existing settlements farther away from the forest; however the problem is yet to be resolved.

In the Yucatan Peninsula, 95\% of the human cases of CL is caused by Leishmania (Leishmania) mexicana Biagi, 1953 emend. Garham, $1962^{5,15}$. In 1987, an incidence rate of 5.08 per 100,000 inhabitants and an allergic index - percentage of persons with a Montenegro intradermal reaction positive to leishmanin (MHOM/MX/87/UADY 68) - up to $47 \%$ was reported in adult men ${ }^{2,6}$.

A strong seasonality in the transmission was demonstrated when the appearance of CL symptoms in both humans and rodents was correlated with the abundance of the antropophilic Lutzomyia cruciata in a Campeche focus ${ }^{3,11}$. In the southern humid forest of the Yucatan Peninsula, transmission of $L$. (L.) mexicana is limited to the months of November to March, when both high humidity and lower temperatures result in a high abundance of adult sand flies concurrent with the multiplication of parasites in the base of rodent tails $3,17,42,43$.

The first attempt to incriminate a disease reservoir close to the Yucatan Peninsula was performed in Belize in the early 1960' $\mathrm{s}^{39}$. The prevalence of Leishmania sp. [probably L. (L.) mexicana] was observed at $40 \%$ in Ototylomys phyllotis Merriam, 1901; 13\% in Nyctomys sumichrasti, Saussure, 1860; and 10\% in Heteromys desmarestianus Desmarest, 1817. However, the parasite was subsequently not found in either $H$. desmarestianus or N. sumichrasti, and only a low prevalence (2-8\%) was later observed in O. phyllotis suggestive of wide variation in the incidence of disease among very close foci over time ${ }^{20}$. In 1987, GRIMALDI positively identified $L$. (L.) mexicana in $N$. sumichrasti ${ }^{26}$. Those findings were not particularly relevant to the Yucatan Peninsula reservoir since the

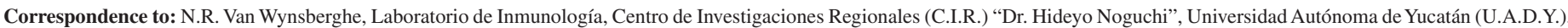
Ave. Itzáes \# 490 x 59 Mérida, Yucatán, CP 97200, México. Tel.: 52 (99) 24-64-12 ext. 133. FAX: 52 (99) 23-61-20. E-mail: nvan@tunku.uady.mx 


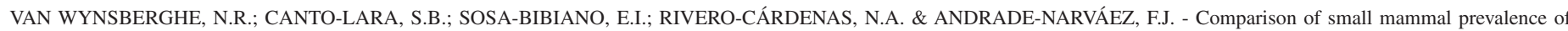
Leishmania (Leishmania) mexicana in five foci of cutaneous leishmaniasis in the State of Campeche, México. Rev. Inst. Med. trop. S. Paulo, 51(2): 87-94, 2009.

northern distribution of $H$. desmarestianus barely reaches the Peninsula and $N$. sumichrasti is absent altogether ${ }^{30,31,32}$.

In 1993-94, a search for the L. (L.) mexicana reservoir in the Yucatan Peninsula was carried out in the village of La Libertad, Escárcega municipality, Campeche State ${ }^{17}$. Reanalyzing those data and limiting them to the transmission season (November to March), a $48 \%$ prevalence of infection was found in small terrestrial rodents. However, since only rodents with suggestive lesions were sampled, the prevalence of infection may have been overestimated. LC lesions were always located at the base of the tail and four species of cricetids were found infected, of which O. phyllotis and Peromyscus yucatanicus J.H. Allen and Chapman, 1897, were incriminated as primary reservoirs of $L$. (L.) mexicana in that focus ${ }^{15,17,43}$. Comparisons with other foci were required to better estimate the prevalence of infection with $L$. (L.) mexicana in small terrestrial rodents and to generalize those results to the whole Yucatan Peninsula.

Thus, in the present study we report the prevalence of both infection and disease caused by $L$. (L.) mexicana in small terrestrial mammals documented during five transmission seasons (1994-95, 1997-98, 2001 to 2004) in five foci of CL in the state of Campeche, Mexico.

\section{MATERIAL \& METHODS}

Study Area: From November 1994 to March 1995, the field study was continued at a site $8 \mathrm{~km}$ southeast of La Libertad, Escárcega, Campeche $\left(20^{\circ} 19.23^{\prime} \mathrm{N}, 90^{\circ} 13.41^{\prime} \mathrm{W}\right)$ (Fig. 1A). However, a more important focus of CL was reported at this time in the municipality of Calakmul, Campeche $(150 \mathrm{~km}$. east of La Libertad) thus, this new area was scouted and preliminary trapping of small mammals was performed during the 1997-1998 transmission season around the villages of $\mathrm{La}$ Guadalupe and Manuel Castillo Brito (Fig. 1B). During the 2001-2002 transmission seasons, two sites were sampled in the most conserved forest fragments of La Guadalupe $\left(18^{\circ} 20.25^{\prime} \mathrm{N}, 89^{\circ} 28.49^{\prime} \mathrm{W}\right)$ and Dos Naciones $\left(17^{\circ} 58.40^{\prime} \mathrm{N}, 8^{\circ} 20.74^{\prime} \mathrm{W}\right.$ - Fig 1B). After one season, for reasons of researcher security, the site at Dos Naciones was replaced by La Virgen ( $18^{\circ} 14.53^{\prime} \mathrm{N}, 89^{\circ} 19.65 \mathrm{~W}$ - Fig. 1B) for the remaining two transmission seasons (2002-2004). Trapping sites were selected at least 3-4 km from villages to minimize trap perturbation by local inhabitants, dogs and other domestic animals.

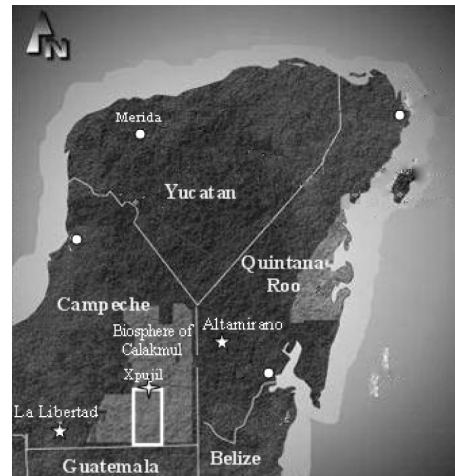

$\mathbf{A}$

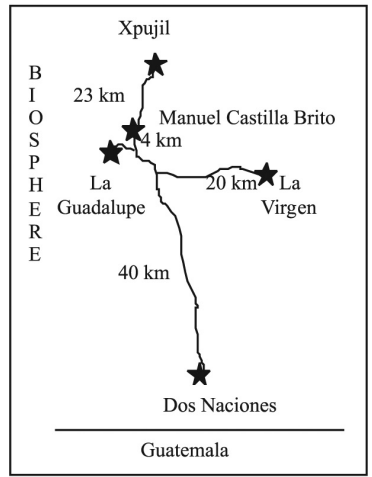

B
Fig. 1 - Location of study sites (A): La Libertad, county of Escárcega, and (B) the remaining sites in the county of Calakmul, state of Campeche, Mexico.
Trapping: All the trapping was performed using collapsible H.B. Sherman traps (Tallahassee, Florida) of $8 \times 8 \times 30 \mathrm{~cm}$, baited with a mixture of maize and sunflower seeds. In the municipality of Calakmul, $20 \%$ of the traps were baited with fruit as well as seeds to attract marsupials. The traps were laid at $15 \mathrm{~m}$ intervals. Sites were visited monthly during each transmission season using the methodology described in Table 1. Trapped animals were identified following Hall's North American mammals ${ }^{28}$, Jones' annotated checklist of mammals from the Yucatan Peninsula ${ }^{31,32}$, and the complete description of H. gaumeri J.A. Allen and Chapman, 1897 , to differentiate it from the rarer $H$. desmarestianus ${ }^{22,30}$.

Table 1

Distribution of trapping methods in the five study areas and during the five transmission seasons

\begin{tabular}{lccc}
\hline $\begin{array}{l}\text { Area } \\
\text { Methods }\end{array}$ & Period & $\begin{array}{c}\text { Duration } \\
(\text { consecutive } \\
\text { nights/month) }\end{array}$ & $\begin{array}{c}\text { Trap layering } \\
\text { per night }\end{array}$ \\
\hline La Libertad & $\begin{array}{c}\text { November 1994 to } \\
\text { March 1995 }\end{array}$ & 10 & $\begin{array}{c}\text { One 10x20 grid } \\
50-70 \text { traps }\end{array}$ \\
$\begin{array}{l}\text { M.C. Brito and } \\
\text { La Guadalupe }\end{array}$ & $\begin{array}{c}\text { November 1997 to } \\
\text { February 1998 }\end{array}$ & $2-3$ & $\begin{array}{c}2-3 \text { transects of } \\
15 \text { traps each }\end{array}$ \\
$\begin{array}{l}\text { La Guadalupe and } \\
\text { Dos Naciones }\end{array}$ & $\begin{array}{c}\text { November 2001 to } \\
\text { March 2002 }\end{array}$ & 6 & $\begin{array}{c}\text { 2 parallel } \\
\text { transects of 30 } \\
\text { traps each }\end{array}$ \\
$\begin{array}{l}\text { La Guadalupe and } \\
\text { La Virgen }\end{array}$ & $\begin{array}{c}\text { November to March } \\
\text { 2002-2003 }\end{array}$ & & $\begin{array}{c}2 \text { parallel } \\
\text { 2003-2004 }\end{array}$ \\
\hline
\end{tabular}

*After analyzing previous results, the number of nights was adjusted.

Search for parasite: Each captured mammal was identified, sexed, and searched for skin lesions mainly at the base of the tail. Since asymptomatic infection exists in rodents, during the 1994-1995 season aspirates of all captured rodents were taken in the field and cultured. Aspirates were taken after cleaning the base of the tail with water and soap to minimize contamination with bacteria. About $0.2 \mathrm{~mL}$ of liquid culture medium (RPMI) with antibiotic (Gentamycin) were inoculated and aspirated repeatedly with an insulin needle subcutaneously either at two centimeters from the base of the tail of asymptomatic animals or at the border of any existing lesion. The aspirates were cultured in a modified Senekjie's medium containing antibiotic ${ }^{44}$. The cultures were kept at $24{ }^{\circ} \mathrm{C}$ and examined weekly for development of leishmanial parasites ${ }^{23}$. An animal was considered positive when at least one promastigote from the culture was observed microscopically and negative if no parasite was observed within one month.

Due to field contamination of cultures, after 1995 all captured mammals were brought to the animal-care facility of the University of Yucatan. The animals were held in quarantine for up to three months in individual cages (19x29x12 cm - K.C.B. Group, Mexico) and received a varied diet including a high-quality rodent chow (Harlan 2018S, Mexico), fresh fruit and vegetables, and water at libitum. An aspirate/culture was collected from each animal a week after arrival. If negative, the procedure was repeated twice at one month intervals. The animal was processed with a lethal dose of pentobarbital either when found positive or at the end of the three months if it survived. Due to the difficulty to aspirate the exact infection 


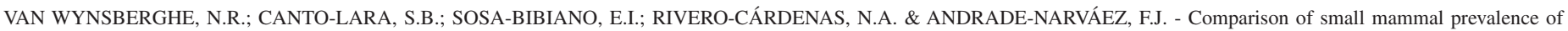
Leishmania (Leishmania) mexicana in five foci of cutaneous leishmaniasis in the State of Campeche, México. Rev. Inst. Med. trop. S. Paulo, 51(2): 87-94, 2009.

site in asymptomatic animals, during the 2001-2003 study, skin biopsies at the tail base were tested by PCR. DNA extraction was performed using a Promega kit (Cat. No. A1125) using the average concentration of 100 $\mathrm{ng} / \mu \mathrm{L}$ for each reaction. For the PCR a La Roche kit (CAT. No. 1578553) was used with the following amplification conditions: initial denaturization at $94{ }^{\circ} \mathrm{C}$ for one min., followed by 30 cycles of denaturalization at $94{ }^{\circ} \mathrm{C}$ during one min., annealing at $60{ }^{\circ} \mathrm{C}$ during one min., and extension at $72{ }^{\circ} \mathrm{C}$ during $1.5 \mathrm{~min}$. and a final extension at $72{ }^{\circ} \mathrm{C}$ during seven min. The amplification reaction was stored at $4{ }^{\circ} \mathrm{C}$ until its use. Since the only species of the subgenus Leishmania found in the Yucatan Peninsula is L. (L.) mexicana, parasite identification was performed to the subgenus level. The primers used were kindly provided by Dr. Peter Melby from the San Antonio University in Texas $^{41}$ (13a: 5'-GTG TGG GAG GGG CGT TCT-3', 13b 5'-ATT TTA CAC CAA CCC CCA GTT-3', M1.1: 5'-CCA GTT TCG ACC GCC GGA GC-3'). The primers 13a and 13b amplified a sequence of the minicircle kinetoplast conserved region of $120 \mathrm{bp}$ to identify the genus Leishmania and the primers 13a and M1.1 amplified a fragment of $105 \mathrm{bp}$ for the subgenus Leishmania. A $2 \mu \mathrm{L}$ volume of DNA solution was amplified in a $25 \mu \mathrm{L}$ reaction mixture containing $1 \mathrm{X}$ buffer, 0.2 $\mathrm{mM}$ deoxynucleoside triphosphates, $1.65 \mathrm{mM} \mathrm{MgCl}, 10 \mathrm{pmol} / \mu \mathrm{L}$ (each) primer, and $2.5 \mathrm{U}$ of Taq DNA polymerase. The positive control was the L. (L.) mexicana reference strain MHET/MX/97/H.d.18 characterized by monoclonal antibodies ${ }^{15}$. The PCR products were visualized in agarose gel ( $2 \%$ with $1 \mu \mathrm{L}$ of ethidium bromide at $0.5 \mu \mathrm{g} / \mu \mathrm{L}$ ) under UV light ${ }^{16}$.

The capture rate was calculated as the number of captured animals divided by the number of traps per night. Relative abundance was calculated for each species. The rate of infection was calculated per species and locality, as the number of positive cultures divided by the number of individuals analyzed.

\section{RESULTS}

Capture rates among transmission seasons did not differ significantly ( $p \geq 0.067$, Table 2 ). All isolated parasites were positively identified as $L$. (L.) mexicana ${ }^{16}$. Overall, $27(22.5 \%)$ out of 120 field aspirates/cultures were lost due to bacterial contamination underscoring the unreliability of this method.

Infection rates during the two first seasons (7\% and 40\%) were significantly lower than those of the last two seasons (both $87 \% ; p \leq 0.0001$ and $p \leq 0.01$, respectively). A significant difference was also observed in the prevalence of infections between 2001-2002 and 2002-2003 ( $p=0.046$ ).

The abundance of small terrestrial mammals was significantly different between Dos Naciones, and both La Guadalupe $(p=0.01)$ and La Libertad $(p=0.04)$. Heteromys gaumeri was the most abundant mammal captured (45\% - Table 3 ) and was significantly more common than any other species [ $p=(0.002-0.05)]$, except $O$. phyllotis $(p=0.12)$ which represented $18 \%$ of the captures and was significantly more abundant than Sigmodon hispidus Say and Ord, 1825 emend. V. Bailey, 1902; Oryzomys melanotis Thomas, 1893; Oryzomys couesi Alston, 1877; Reithrodontomys gracilis J.A. Allen and Chapman, 1897; and marsupials $(p \leq 0.04)$.

Tail depigmentation in $H$. gaumeri was so common that was not considered as a possible sign of leishmaniasis during the first season. However, during the following transmission seasons, tail's dryness and/ or depigmentation were registered in all animals (Table 4). None of the
Table 2

Temporal and spatial distributions of trapping success and prevalence of Leishmania (Leishmania) mexicana in small mammals from the state of Campeche, Mexico, during five transmission seasons

\begin{tabular}{|c|c|c|c|c|c|c|}
\hline Month & Year & Site & Capture & $\begin{array}{l}\text { Capture } \\
\text { rate }\end{array}$ & $\begin{array}{c}\text { Checked for } \\
\text { infection }\end{array}$ & $\begin{array}{c}\text { Infection } \\
\text { rate }\end{array}$ \\
\hline Nov. & 1994 & La Libertad & 66 & $6.7 \%$ & 39 & $2.6 \%$ \\
\hline Dec. & & & 54 & $5.3 \%$ & 32 & $6.3 \%$ \\
\hline Feb. & 1995 & & 70 & $6.8 \%$ & 24 & $20.8 \%$ \\
\hline Mar. & & & 37 & $12.3 \%$ & 19 & $0 \%$ \\
\hline Total & & & 227 & $6.8 \%$ & 114 & $7 \%$ \\
\hline \multirow[t]{2}{*}{ Nov. } & 1997 & M. C. Brito & 3 & $3.3 \%$ & 3 & $33 \%$ \\
\hline & & La Guadalupe & 8 & $8.9 \%$ & 7 & $57 \%$ \\
\hline Dec. & & M.C. Brito & 7 & $2.6 \%$ & 3 & $66 \%$ \\
\hline Jan. & 1998 & M.C. Brito & 2 & $3.3 \%$ & 1 & $0 \%$ \\
\hline Feb. & & M.C. Brito & 4 & $2.2 \%$ & 1 & $0 \%$ \\
\hline Total & & & 24 & $3.5 \%$ & 15 & $40 \%$ \\
\hline Nov. & 2001 & 2 Naciones & 5 & $6.3 \%$ & 4 & $0 \%$ \\
\hline Dec. & & La Guadalupe & 19 & $4.0 \%$ & 19 & $63 \%$ \\
\hline Jan. & 2002 & 2 Naciones & 12 & $4.6 \%$ & 6 & $50 \%$ \\
\hline Feb. & & La Guadalupe & 16 & $4.8 \%$ & 15 & $93 \%$ \\
\hline Mar. & & 2 Naciones & 1 & $3.9 \%$ & 1 & $0 \%$ \\
\hline Total & & & 53 & $3.7 \%$ & 45 & $64 \%$ \\
\hline Nov. & 2002 & La Guadalupe & 2 & $3.4 \%$ & 2 & $100 \%$ \\
\hline Dec. & & La Virgen & 16 & $6.2 \%$ & 16 & $94 \%$ \\
\hline Jan. & 2003 & La Guadalupe & 13 & $6.2 \%$ & 12 & $100 \%$ \\
\hline Feb. & & La Virgen & 11 & $5.0 \%$ & 10 & $70 \%$ \\
\hline Mar. & & La Guadalupe & 5 & $2.4 \%$ & 5 & $60 \%$ \\
\hline Total & & & 47 & $4.9 \%$ & 45 & $87 \%$ \\
\hline Nov. & 2003 & La Guadalupe & 14 & $6.9 \%$ & 12 & $83 \%$ \\
\hline Dec. & & La Virgen & 2 & $1.1 \%$ & 2 & $100 \%$ \\
\hline Jan. & 2004 & La Guadalupe & 11 & $5.3 \%$ & 8 & $88 \%$ \\
\hline Feb. & & La Virgen & 9 & $6.3 \%$ & 9 & $87 \%$ \\
\hline Mar. & & La Guadalupe & 14 & $9.5 \%$ & 14 & $86 \%$ \\
\hline Total & & & 50 & $5.7 \%$ & 45 & $87 \%$ \\
\hline
\end{tabular}

Sigmodon, R. gracilis and marsupial Marmosa mexicana Merriam, 1897, presented signs of ulcer, scab, or scar. The highest prevalence of these signs was found in the Calakmul's $H$. desmarestianus (3/8 with scab), followed by $P$. yucatanicus (3/17 with ulcer and scar), and $O$. melanotis (2/13 with ulcer).

During the transmission season 1994-1995 in La Libertad, parasites of $L$. (L.) mexicana were recovered by field aspirates/cultures only in $O$. phyllotis and P. yucatanicus. The total prevalence of $L$. (L.) mexicana in Calakmul was $75 \%(\mathrm{n}=155)$, and ranged from $100 \%$ in $H$. desmarestianus $(\mathrm{n}=9)$ to $39 \%$ in $P$. yucatanicus $(\mathrm{n}=18)$. In the municipality of Calakmul, $H$. gaumeri were more frequently asymptomatic than symptomatic (56-58\%). In both areas, Ototylomys represented $50 \%$ of asymptomatic animals.

\section{DISCUSSION}

The Yucatan Peninsula is a Biotic Province ${ }^{9,24}$ with two endemic rodent species: the Gaumer's spiny pocket-mouse, H. gaumeri; and the 


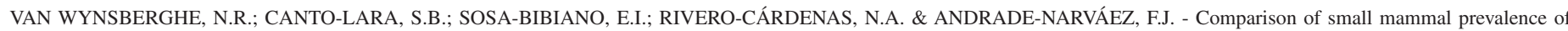
Leishmania (Leishmania) mexicana in five foci of cutaneous leishmaniasis in the State of Campeche, México. Rev. Inst. Med. trop. S. Paulo, 51(2): 87-94, 2009.

Table 3

Relative abundance of mammal species captured in five sites of the state of Campeche, Mexico

\begin{tabular}{|c|c|c|c|c|c|c|c|}
\hline \multirow{2}{*}{$\begin{array}{l}\text { Capture Site } \\
\text { Species }\end{array}$} & \multirow{2}{*}{$\begin{array}{c}\text { La } \\
\text { Libertad }\end{array}$} & \multirow{2}{*}{$\begin{array}{l}\text { M.C. } \\
\text { Brito }\end{array}$} & \multicolumn{2}{|c|}{ La Guadalupe } & \multirow{2}{*}{ Dos Naciones } & \multirow{2}{*}{ La Virgen } & \multirow{2}{*}{ Total } \\
\hline & & & $1997-8$ & 2001-4 & & & \\
\hline \multicolumn{8}{|l|}{ Heteromid rodents } \\
\hline Heteromys gaumeri & $54 \%$ & $36 \%$ & $13 \%$ & $36 \%$ & $72 \%$ & $32 \%$ & $46 \%$ \\
\hline H. desmarestianus & - & - & $12 \%$ & $0 \%$ & $0 \%$ & $21 \%$ & $2 \%$ \\
\hline \multicolumn{8}{|l|}{ Cricetid rodents } \\
\hline Ototylomys phyllotis & $14 \%$ & $28 \%$ & $13 \%$ & $22 \%$ & $6 \%$ & $34 \%$ & $19 \%$ \\
\hline Peromyscus yucatanicus & $16 \%$ & $36 \%$ & $50 \%$ & $15 \%$ & $0 \%$ & $0 \%$ & $13 \%$ \\
\hline Sigmodon hispidus & $11 \%$ & $0 \%$ & $0 \%$ & $9 \%$ & $11 \%$ & $0 \%$ & $8 \%$ \\
\hline Oryzomys melanotis & $0 \%$ & $0 \%$ & $0 \%$ & $11 \%$ & $6 \%$ & $5 \%$ & $5 \%$ \\
\hline Reithrodontomys gracilis & $5 \%$ & $0 \%$ & $0 \%$ & $7 \%$ & $0 \%$ & $0 \%$ & $4 \%$ \\
\hline Marsupials & - & $0 \%$ & $12 \%$ & $1 \%$ & $6 \%$ & $8 \%$ & $3 \%$ \\
\hline Total of individuals & 227 & 16 & 8 & 94 & 18 & 38 & 401 \\
\hline
\end{tabular}

Table 4

Clinical signs and disease prevalence of L. (L.) mexicana in mammal species from both municipalities of Escárcega (La Libertad, 1994-95) and Calakmul (three sites, four transmission seasons), state of Campeche, Mexico. ( $\mathrm{Nd}=$ not done)

\begin{tabular}{|c|c|c|c|c|c|c|c|c|}
\hline $\begin{array}{l}\text { Symptom } \\
\text { Species }\end{array}$ & Municipality & $\mathrm{N}$ & $\begin{array}{l}\text { Dryness } \\
\text { Depigm. }\end{array}$ & $\begin{array}{l}\text { Edema } \\
\text { Erythema }\end{array}$ & Ulcer & Scab & Scar & $\begin{array}{l}\text { Disease } \\
\text { rate }\end{array}$ \\
\hline \multicolumn{9}{|l|}{ Heteromid rodent } \\
\hline \multirow[t]{2}{*}{ Heteromys gaumeri } & Escárcega & 26 & $\mathrm{Nd}$ & $0 \%$ & $0 \%$ & $0 \%$ & $0 \%$ & $0 \%$ \\
\hline & Calakmul & 51 & $25 \%$ & $0 \%$ & $0 \%$ & $6 \%$ & $0 \%$ & $31 \%$ \\
\hline \multirow[t]{2}{*}{ Heteromys desmarestianus } & Escárcega & - & - & - & - & - & - & - \\
\hline & Calakmul & 8 & $0 \%$ & $0 \%$ & $0 \%$ & $38 \%$ & $0 \%$ & $38 \%$ \\
\hline \multicolumn{9}{|l|}{ Cricetid rodent } \\
\hline \multirow[t]{2}{*}{ Ototylomys phyllotis } & Escárcega & 15 & $13 \%$ & $13 \%$ & $0 \%$ & $0 \%$ & $0 \%$ & $27 \%$ \\
\hline & Calakmul & 34 & $32 \%$ & $12 \%$ & $6 \%$ & $0 \%$ & $0 \%$ & $50 \%$ \\
\hline \multirow[t]{2}{*}{ Peromyscus yucatanicus } & Escárcega & 17 & $29 \%$ & $0 \%$ & $12 \%$ & $0 \%$ & $6 \%$ & $47 \%$ \\
\hline & Calakmul & 12 & $75 \%$ & $0 \%$ & $8 \%$ & $0 \%$ & $8 \%$ & $92 \%$ \\
\hline \multirow[t]{2}{*}{ Sigmodon hispidus } & Escárcega & 11 & $0 \%$ & $0 \%$ & $0 \%$ & $0 \%$ & $0 \%$ & $0 \%$ \\
\hline & Calakmul & 10 & $10 \%$ & $0 \%$ & $0 \%$ & $0 \%$ & $0 \%$ & $10 \%$ \\
\hline \multirow[t]{2}{*}{ Oryzomys melanotis } & Escárcega & 0 & - & - & - & - & - & - \\
\hline & Calakmul & 13 & $31 \%$ & $23 \%$ & $15 \%$ & $0 \%$ & $0 \%$ & $69 \%$ \\
\hline \multirow[t]{2}{*}{ Reithrodontomys gracilis } & Escárcega & 2 & $50 \%$ & $0 \%$ & $0 \%$ & $0 \%$ & $0 \%$ & $0 \%$ \\
\hline & Calakmul & 7 & $14 \%$ & $29 \%$ & $0 \%$ & $0 \%$ & $0 \%$ & $43 \%$ \\
\hline \multicolumn{9}{|l|}{ Marsupials } \\
\hline \multirow[t]{2}{*}{ Marmosa mexicana } & Escárcega & - & - & - & - & - & - & - \\
\hline & Calakmul & 2 & $0 \%$ & $0 \%$ & $0 \%$ & $0 \%$ & $0 \%$ & $0 \%$ \\
\hline \multirow[t]{2}{*}{ Rates } & Escárcega & 72 & $11 \%$ & $3 \%$ & $3 \%$ & $0 \%$ & $1 \%$ & $18 \%$ \\
\hline & Calakmul & 137 & $28 \%$ & $7 \%$ & $4 \%$ & $4 \%$ & $1 \%$ & $43 \%$ \\
\hline
\end{tabular}

Yucatan deer-mouse, P. yucatanicus ${ }^{21}$. Since the distribution of mammals is known and their abundance can be calculated, the prevalence of $L$. (L.) mexicana should be predictable over the whole state of Campeche. However, in the state of Campeche, the seasonal prevalence of infection was significantly higher in the municipality of Calakmul than in La Libertad (municipality of Escárcega) and seemed to increase over time (Table 2) to an alarming prevalence of $87 \%$, indicating the need for epidemiological human studies to assess the leishmaniasis situation in that region.
BECERRA \& MUÑOZ considered a reservoir to be any person, animal, plant, soil, or substance (or combination of these) in which an infectious agent normally lives and multiplies, on which it depends primarily for survival, and where it reproduces itself in such manner that it can be transmitted to a susceptible host ${ }^{10}$. The World Health Organization enumerated five criteria to incriminate a primary reservoir of leishmaniases ${ }^{45}$. An important criterion was that a reservoir species should be sufficiently abundant to provide a significant food source for sand flies. Since capture rates were significantly homogeneous among both sites and 


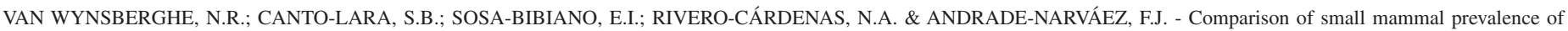
Leishmania (Leishmania) mexicana in five foci of cutaneous leishmaniasis in the State of Campeche, México. Rev. Inst. Med. trop. S. Paulo, 51(2): 87-94, 2009.

months, relative abundance among species could be compared (Table 3 ). In all sites, H. gaumeri was the most abundant rodent (46\%); however this species had never been previously reported to be infected by Leishmania spp. The two primary reservoirs of $L$. (L.) mexicana incriminated in La Libertad ${ }^{17}$ O. phyllotis and P. yucatanicus were the next most abundant small mammals (19\% and $13 \%$, respectively). Contrary to the endemic Yucatan deer-mouse, the widespread big-eared climbing rat is found in Belize, just southeast of the Yucatan, where its prevalence for Leishmania spp. varied from $40 \%(\mathrm{n}=20)$ to $2 \%(\mathrm{n}=58)^{20,38,39}$ and represented the first $(66 \%, \mathrm{n}=419)$ and the fourth $(13 \%, \mathrm{n}=160)$ positions for relative abundance, respectively (Table 5). Since sand flies prefer humid forest ${ }^{42}$, the maize-field habitat of $S$. hispidus were not targeted for study, but in an area of Belize where this hispid cotton-rat was the most abundant species $(47 \%, \mathrm{n}=897)$ only one $S$. hispidus $(\mathrm{n}=43)$ was found with a lesion suggestive of Leishmania on its tail ${ }^{20}$ (Table 5). No O. melanotis were captured in La Libertad (1994-1995) because they were removed the previous year ${ }^{17}$ and this species seemed to have low rates of multiplication and recolonization (Table 3). HERRER et al. ${ }^{29}$ found a similar situation with another rice rat, Oryzomys capito which was found to be restricted to a small area and its population decreased markedly, apparently due to intensive trapping. Hence, the least abundant species such $O$. coues $i$, $O$. melanotis, $R$. gracilis, and marsupials are very unlikely to be primary reservoirs of $C L$ in the Yucatan Peninsula.

Another criterion to incriminate a primary reservoir of Leishmania stated that the infection in a reservoir species should be relatively nonpathogenic, that is the infection should not lower the survival possibility of the animal since it has to live until the next transmission season $^{45}$, which is more than seven months in the Peninsula. In other words, the immune system of the reservoir must react to the presence of the parasite in such a manner that while preventing it from doing any irrevocable damage, the parasite is not eliminated ${ }^{14}$. In Texas (USA),

Table 5

Prevalence distribution of Leishmania in small mammals from November to March in Campeche, Yucatan Peninsula, Mexico and just south in Belize, taken from both published data and the present paper (sample size in parenthesis). Belize 1960-63 (blood, liver and spleen cultures) ${ }^{39}$; Belize, 1964-66 (lesions' smears) ${ }^{20}$; Escárcega, Mexico, 1993-94 (lesions' smears and aspirates/cultures) ${ }^{17}$; and in the present study, Escárcega, Mexico, 1994-95 (aspirates/cultures from base of tail); Calakmul, Mexico, 1997-98 $\alpha$ Manuel Castilla Brito and $\beta$ La Guadalupe (aspirates/cultures from base of tail); Calakmul, Mexico, 2001-2004, $\beta$ La Guadalupe, $\gamma$ Dos Naciones, and $\delta$ La Virgen (aspirates/cultures and PCR from base of tail).

\begin{tabular}{|c|c|c|c|c|c|c|}
\hline Location & $\begin{array}{c}\text { Cayo District, } \\
\text { Belize. } \\
\text { 1960-63 }\end{array}$ & $\begin{array}{c}\text { Cayo District, } \\
\text { Belize. } \\
1964-66\end{array}$ & $\begin{array}{c}\text { Escárcega, } \\
\text { Campeche } \\
\text { Mexico. } \\
\text { 1993-1994 }\end{array}$ & $\begin{array}{c}\text { Escárcega, } \\
\text { Campeche } \\
\text { Mexico. } \\
\text { 1994-1995 }\end{array}$ & $\begin{array}{c}\text { Calakmul, } \\
\text { Campeche } \\
\text { Mexico. } \\
\text { 1997-98 }\end{array}$ & $\begin{array}{c}\text { Calakmul, } \\
\text { Campeche } \\
\text { Mexico. } \\
\text { 2001-2004 }\end{array}$ \\
\hline $\begin{array}{l}\text { Heteromidae } \\
\text { Heteromys gaumeri }\end{array}$ & Out of range & Out of range & $0 \%(9)$ & $0 \%(26)$ & $\begin{array}{l}0 \%(4)^{\alpha} \\
0 \%(1)^{\beta}\end{array}$ & $\begin{array}{c}88 \%(32)^{\beta} \\
29 \%(7)^{\gamma} \\
67 \%(12)^{\delta}\end{array}$ \\
\hline Heteromys desmarestianus & $10 \%(58)$ & $0 \%(20)$ & Out of range & Out of range & $100 \%(1)^{\beta}$ & $100 \%(8)^{\delta}$ \\
\hline $\begin{array}{l}\text { Cricetidae } \\
\text { Tylomys nudicaudus }\end{array}$ & $0 \%(26)$ & $0 \%(3)$ & Out of range & Out of range & Out of range & Out of range \\
\hline Nyctomys sumichrasti & $13 \%(8)$ & $0 \%(23)$ & Out of range & Out of range & Out of range & Out of range \\
\hline Ototylomys phyllotis & $40 \%(20)$ & $\begin{array}{c}2 \%(58) \\
4 \%(278) \\
8 \%(13)\end{array}$ & $44 \%(18)$ & $27 \%$ & $\begin{array}{l}67 \%(3)^{\alpha} \\
100 \%(1)^{\beta}\end{array}$ & $\begin{array}{c}100 \%(20)^{\beta} \\
0 \%(1)^{\gamma} \\
100 \%(13)^{\delta}\end{array}$ \\
\hline Peromyscus yucatanicus & Out of range & Out of range & $50 \%(10)$ & $18 \%(17)$ & $\begin{array}{l}25 \%(4)^{\alpha} \\
50 \%(4)^{\beta}\end{array}$ & $40 \%(10)^{\beta}$ \\
\hline Sigmodon hispidus & - & $3 \%(43)$ & $18 \%(11)$ & $0 \%(11)$ & & $\begin{array}{l}63 \%(8)^{\beta} \\
50 \%(2)^{\gamma}\end{array}$ \\
\hline Oryzomys couesi & $0 \%(1)$ & - & - & - & - & - \\
\hline Oryzomys alfaroi & $0 \%(7)$ & - & Out of range & Out of range & Out of range & $\begin{array}{l}\text { Out of } \\
\text { range }\end{array}$ \\
\hline Oryzomys melanotis & & $0 \%(12)$ & $93 \%(14)$ & - & & $\begin{array}{c}90 \%(10)^{\beta} \\
0 \%(1)^{\gamma} \\
100 \%(2)^{\delta}\end{array}$ \\
\hline Reithrodontomys gracilis & $0 \%(2)$ & $0 \%(3)$ & $0 \%(1)$ & $0 \%(2)$ & & $86 \%(7)^{\beta}$ \\
\hline $\begin{array}{l}\text { Marsupials } \\
\text { Marmosa mexicana }\end{array}$ & Not done & Not done & $0 \%(1)$ & Not done & $100 \%(1)^{\beta}$ & $50 \%(2)^{\delta}$ \\
\hline
\end{tabular}




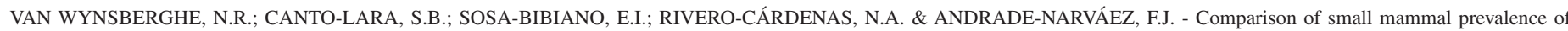
Leishmania (Leishmania) mexicana in five foci of cutaneous leishmaniasis in the State of Campeche, México. Rev. Inst. Med. trop. S. Paulo, 51(2): 87-94, 2009.

a distant focus of $L$. (L.) mexicana, parasites were recovered from the ears of ten Neotoma micropus Baird, $1855^{18,27,33,34,41}$. In Belize, one $H$. desmarestianus was captured with both ears infected and smears were positive for amastigotes ${ }^{20}$. However, in La Libertad (1994-1995), aspirates from 28 spiny pocket-mice's ears were cultivated without positive results. As generally observed in Latin-America, the clinical symptoms of $L$. (L.) mexicana in rodents of Yucatan Peninsula were mild and always restricted to the dorsal side of the tail mostly close to its base $e^{7,17,20,38,39,43}$.

In $H$. gaumeri, the discoloration at the level of vertebrae was first considered normal and not registered for the Gaumer's spiny pocket-mice collected during the 1994-1995 season (Table 4). However, the results of the next research periods proved that in Heteromys, this symptom was a fair indicator of CL. In H. desmarestianus, scabs were associated with dryness, depigmentation and alopecia. In the $O$. melanotis, tail discoloration was the best indicator of $\mathrm{CL}^{17,43}$ and was always present with other symptoms. However, discoloration and dryness of the tail was not a reliable indicator in $P$. yucatanicus, since no parasites could be recovered by aspirates/culture in six of the eight "symptomatic" Yucatan deer-mice (75\%), and by either aspirates/cultures or PCR in nine of the $11(73 \%)$. Thus, this clinical sign overestimated disease rates in Peromyscus (47\% and $92 \%$ - Table 4). In the research center's breeding colony of P. yucatanicus, both dryness and depigmentation were often associated to the diet. Thus, diagnosis should not be generalized to all species, and additional research is needed to assess the importance of both depigmentation and dryness for the diagnosis of CL.

As in humans the surest clues of CL were ulcers, scabs and scars, but their total prevalence in mammals was fairly low (7\% - Table 4). The highest rates of these signs were found in $H$. desmarestianus, $P$. yucatanicus, and $O$. melanotis from Calakmul. Three mammal species (S. hispidus, $R$. gracilis, and $M$. mexicana) never presented those signs. In the previous study in $\mathrm{La}$ Libertad (1993-1994), the only two infected Sigmodon showed either scar or ulcer, and parasites in one of them produced metastasis up to its ears which would reduce its survival in the wild ${ }^{43}$, proving that the short-lived hispid cotton-rat is unlikely to be an effective reservoir of CL. Except for the latter case, the present results (Table 4) showed that the infection seemed relatively nonpathogenic in small terrestrial mammals.

This paper presents the first record of infection identified as $L$. (L.) mexicana in three rodents: H. gaumeri, H. desmarestianus, and $R$. gracilis; and one marsupial: M. mexicana. Thus, all small terrestrial mammals of the Peninsula seemed to be able to harbor the parasite. The World Health Organization stated that the proportion of specimens that become infected during their life should be considerable and may exceed $20 \%$. During the 1994-95 transmission season in La Libertad, only O. phyllotis (27\%) and P. yucatanicus (18\%), were found infected (Table 5) which corroborated their role as reservoirs of $L$. (L.) mexicana ${ }^{17}$. In Calakmul, the species prevalence reached an unexpectedly high peak $(75 \%)$ and with the exception of $P$. yucatanicus, all species had a prevalence of infection that exceeded $50 \%$ (Table 5). This marked difference between the two municipalities might reflect either a steadily increase of the prevalence of CL in Campeche or a local outbreak. Further investigation is clearly needed to assess the consequences for human health.

Heteromys gaumeri, one of the two endemic rodents, had a surprisingly high rate of infection (68\%) in Calakmul, although the Gaumer's spiny pocket-mouse was never found to be infected in La Libertad (Table 5). In
Belize, H. desmarestianus was captured with inconspicuous lesions, that were rarely ulcerated, on the base of the tail with a prevalence of $10 \%$ (Table 5) due to Leishmania, probably $L$. (L.) mexicana ${ }^{38,39}$. There, the Desmarest's spiny pocket-mouse had the highest relative abundant $36 \%(n=160)^{39}$. In the municipality of Calakmul, the presence of heavily infected Heteromidae demonstrated variations among apparently very similar micro-foci and the existence of different species. This shifting of reservoir might be one of the reasons for the surprisingly high prevalence of $L$. (L.) mexicana in Calakmul. The potential variation in the habitat between Escárcega and Calakmul is currently been analyzed.

Finally, the role of the marsupial, Marmosa in the transmission of $L$. (L.) mexicana is unknown. In line with the present study, lesions have not been observed in any of the M. mexicana (ex- murina) captured in Belize $^{20}$, or Marmosa spp. captured in Brazil ${ }^{13}$ or Peru ${ }^{40}$. In Brazil, 1/13 M. murina Merriam, 1897, was found with a leishmanial ulcer on the tail $^{36,37}$, and parasites from two asymptomatic M. alstoni (ex- cinerea) J.A. Allen, 1900 were identified by isoenzymes as $L$. (L.) amazonensis (MMAR/BR/79/IM-42 \& MMAR/BR/79/IM-56) ${ }^{8}$.

Thus, each endemic area, and even each micro focus, has its own characteristics which have a direct repercussion on the type of leishmaniasis reservoirs, making generalizations a difficult task. The high species richness of mammals in the tropical regions of the New World implies that each focus of leishmaniasis has to be investigated separately. Only detailed and wide-ranging eco-epidemiological research will permit to generalize the results to similar habitats such as the whole Yucatan Peninsula.

\section{RESÚMEN}

\section{Comparación de las prevalencias de Leishmania (Leishmania) mexicana en mamíferos pequeños en cinco focos de leishmaniosis cutánea en el estado de Campeche, México}

En la Península de Yucatán, México, la Leishmaniosis Cutánea es causada por Leishmania (L.) mexicana en $95 \%$ de los casos humanos, con una incidencia de $5.08 \%$ por cada 100,000 habitantes. El ciclo de transmisión se limita a la estación de invierno (noviembre- marzo). Un estudio de mamíferos silvestres incrimina a Ototylomys phyllotis y Peromyscus yucatanicus como reservorios primarios de L. (L.) mexicana en el foco de infección de La Libertad, Campeche. En el presente estudio, se documenta la prevalencia de infección/enfermedad causada por $L$. (L.) mexicana en pequeños mamíferos, durante cinco estaciones de transmisión (1994-2004) en cinco focos de CL del estado de Campeche. Los focos separados por solamente $100 \mathrm{~km}$. de distancia, aún cuando tienen abundancias relativas de pequeños roedores similares, fueron significativamente diferentes en relación a la prevalencia de síntomas así como de infección. Las tasas de transmisión y las especies de reservorios parecen estar cambiando tanto en el tiempo como en el espacio, lo cual impide el establecimiento de adecuadas medidas de control de la enfermedad aún en un área endémica tan pequeña como lo es el sur de la Península de Yucatán.

\section{ACKNOWLEDGEMENTS}

We thank the C.I.R.-U.A.D.Y. administration for logistical support, the inhabitants of La Libertad, La Guadalupe, Castilla Brito, Dos Naciones, 
VAN WYNSBERGHE, N.R.; CANTO-LARA, S.B.; SOSA-BIBIANO, E.I.; RIVERO-CÁRDENAS, N.A. \& ANDRADE-NARVÁEZ, F.J. - Comparison of small mammal prevalence of Leishmania (Leishmania) mexicana in five foci of cutaneous leishmaniasis in the State of Campeche, México. Rev. Inst. Med. trop. S. Paulo, 51(2): 87-94, 2009.

and La Virgen for providing facilities, and particularly Dr. A. Chiñas of the rural clinic of Ricardo Payro (IMSS) for his invaluable help in the coordination of the field activities, Alma Gloria Damián Centeno, José Cupertino Moo Huchim, Marcial Cua Ake, and Dolores Peregrina Salazar Pech of the Laboratory of Immunology provided technical support, Dr. Eric Dumonteil for comments on the manuscript, and Dr. Williams Trevor for the editing. This study was supported by a grant from the Mexican National Council for Science and Technology (CoNaCyT SEP-2004CO1-46390) with SEMARNAP permits (704.1.7.2; SMA/084/1997; DOO 02-1152; and SGPA/DGVS/4659) to collect, transports, and use the animals for the present research.

\section{REFERENCES}

1. ABRANCHES, P. - Reservoirs of visceral leishmaniasis. In HART, D.T., ed Leishmaniasis: the current status and new strategies for control. New York, Plenum Press, 1987. p. 61-70.

2. ALBERTOS-ALPUCHE, N.E.; ANDRADE-NARVÁEZ, F.J.; BURGOS-PATRÓN, J.P. \& VÁSQUEZ-PÉREZ, A. - Leishmaniasis cutánea localizada: índice alérgico en la comunidad de Becanchén, Tekax, Yucatán, México. Rev. Bioméd. (Méx.), 7: 11-18, 1996.

3. ANDRADE-NARVÁEZ, F.J.; CANTO-LARA, S.B.; VAN WYNSBERGHE, N.R. et al. - Seasonal transmission of Leishmania (Leishmania) mexicana in the state of Campeche, Yucatan Peninsula, Mexico. Mem. Inst. Oswaldo Cruz, 98: 995-998, 2003 .

4. ANDRADE-NARVÁEZ, F.; GARCIA-MÍSS, M.R.; CRUZ-RUIZ, A.L.; CANTO-LARA S.B. \& SIMMONDS-DIAZ, E. - Preliminary study of clinical, hispathological, and immunological correlation of Mexican cutaneous leishmaniasis in man. Arch. Invest. méd., 15: 267-280, 1984

5. ANDRADE-NARVÁEZ, F.J.; SIMMONDS-DÍAZ, E.; RICO-AGUILAR, S. et al. Incidence of localized cutaneous leishmaniasis (chiclero's ulcer) in Mexico. Trans. roy. Soc. trop. Med. Hyg., 84: 219-220, 1990.

6. ANDRADE NARVÁEZ, F; VALERIO CASTRO, E.; SIMMONDS DÍAZ, E. et al. Leishmaniasis cutánea mexicana. Índice alérgico en una población militar ubicada en una zona endémica. Rev. Sanid. milit. (Méx), 39:152-154, 1985.

7. ARIAS, J.R. \& NAIFF, R.D. - The principal reservoir host of cutaneous leishmaniasis in the urban areas of Manaus, Central Amazon of Brazil. Mem. Inst. Oswaldo Cruz, 76: $279-286,1981$

8. ARIAS, J.R.; NAIFF, R.D.; MILES, M.A. \& DE SOUZA, A.A. - The opossum, Didelphis marsupialis (Marsupialia: Didelphidae), as a reservoir host of Leishmania braziliensis guyanensis in the Amazon Basin of Brazil. Trans. roy. Soc. trop. Med. Hyg., 75: $537-541,1981$.

9. BARRERA, A. - La Península de Yucatán como provincia biótica. Rev. Soc. mex. Hist. nat., 23: 71-105, 1962.

10. BECERRA, J. \& MUÑOZ, M. - A strategy for control of cutaneous leishmaniasis through the CIMDER's primary health care model. In: WIJEYARATNE, P.; GOODMAN, T. \& ESPINAL, C., ed. Leishmaniasis control strategies: a critical evaluation of IDRC-supported research. Ottawa, International Development Research CenterMR322e, 1992. p. 19-31.

11. BELTRAN, E. \& BUSTAMANTE, M.E. - Datos epidemiológicos acerca de la "úlcera de los chicleros" (leishmaniasis americana) en México. Rev. Inst. Salubr. Enferm. trop., 3: 1-28, 1942.

12. BIAGI, F.F.; MARROQUIN, F. \& GONZALEZ A. - Distribución geográfica de la leishmaniasis cutánea en México. Medicina (Méx.), 38: 444-446, 1938.
13. BRANDÃO-FILHO, S.P.; DE CARVALHO, F.G.; DE BRITO, M.E.; ALMEIDA F.A. \& NASCIMENTO, L.A. - American cutaneous leishmaniasis in Pernambuco, Brazil: eco-epidemiological aspects in "Zona da Mata" region. Mem. Inst. Oswaldo Cruz, 89: 445-449, 1994.

14. BRAY, R.S. - Zoonoses and leishmaniasis. In HART, D.T., ed. Leishmaniasis: the current status and new strategies for control. New York, Plenum Press, 1987. p. $57-60$.

15. CANTO-LARA, S.B.;VANWYNSBERGHE, N.R.;VARGAS-GONZÁLEZ,A.; OJEDAFARFÁN, F.F. \& ANDRADE-NARVÁEZ, F.J. - Use of monoclonal antibodies for the identification of Leishmania spp. isolated from humans and wild rodents in the state of Campeche, Mexico. Mem. Inst. Oswaldo Cruz, 94: 305-309, 1999.

16. CANTO-LARA, S.B.; VAN WYNSBERGHE, N.R.; SOSA-BIBIANO, E.I. \& ANDRADE-NARVÁEZ, F.J. - Detection and identification of Leishmania kDNA in small mammals by the polymerase chain reaction in Campeche, Mexico. (Submitted).

17. CHABlÉ-SANTOS, J.B., VAN WYNSBERGHE, N.R.; CANTO-LARA, S.B. \& ANDRADE-NARVÁEZ, F.J. - Isolation of Leishmania (L.) mexicana from wild rodents and their possible role in the transmission of localized cutaneous leishmaniasis in the State of Campeche, Mexico. Amer. J. trop. Med. Hyg., 53: 141-145, 1995.

18. CRAIG, T.M.; BARTON, C.L.; MERCER, S.H.; DROLESKEY, B.E. \& JONES, L.P. - Dermal leishmaniasis in a Texas cat. Amer. J. trop. Med. Hyg., 35: 1100-1102, 1986

19. DESJEUX, P. - Leishmaniasis. Nature Rev. Microbiol., 2: 692, 2004

20. DISNEY, R.H.L. - Observations on a zoonosis: leishmaniasis in British Honduras. J. appl. Ecol., 5: 1-59, 1968

21. DOWLER, R.C. \& ENGSTROM, M.D. - Distributional records of mammals from the southwestern Yucatan Peninsula of Mexico. Ann. Carnagie Museum, 57: 159-166, 1988

22. ENGSTROM, M.D.; GENOWAYS, H.H. \& TUCKER, P.K. - Morphological variation, karyology, and systematic relationships of Heteromys gaumeri (Rodentia: Heteromyidae). In PATTERSON, B.D. \& TIMM, R.M., ed. Studies in neotropical mammalogy: essays in honor of Philip Hershkovitz. Fieldiana Zool., New Ser., 39: 289-303, 1987.

23. EVANS, D.; GODFREY, D.; LANHAM, S. et al. - Handbook on isolation characterization and cryopreservation of Leishmania. Geneva, UNDP/WorldBank/ WHO, 1989.

24. GOLDMAN, E.A. \& MOORE, R.T. - The biotic provinces of Mexico. J. Mammalogy, 26: $347-360,1945$.

25. GRAMICCIA, M. \& GRADONI, L. - The current status of zoonotic leishmaniases and approaches to disease control. Int. J. Parasit., 35: 1169-1180, 2005.

26. GRIMALDI Jr., G.; DAVID, J.R. \& McMAHON-PRATT, D. - Identification and distribution of New World Leishmania species characterized by serodeme analysis using monoclonal antibodies. Amer. J. trop. Med. Hyg., 36: 270-287, 1987.

27. GROGL, M.; KREUTZER, R.D.; McHUGH, C.P. \& MARTIN, R.K. - Characterization of a Leishmania isolate from the rodent host Neotoma micropus collected in Texas and comparison with human isolates. Amer. J. trop. Med. Hyg., 45: 714-722, 1991.

28. HALL, E.R. - The Mammals of North America. 2. ed. New York, John Wiley \& Sons, 1981.

29. HERRER, A.; TELFORD Jr., S.R. \& CHRISTENSEN, H.A. - Enzootic cutaneous Leishmaniasis in eastern Panama. I. Investigation of the infection among forest mammals. Ann. trop. Med. Parasit., 65: 349-358, 1971. 
VAN WYNSBERGHE, N.R.; CANTO-LARA, S.B.; SOSA-BIBIANO, E.I.; RIVERO-CÁRDENAS, N.A. \& ANDRADE-NARVÁEZ, F.J. - Comparison of small mammal prevalence of Leishmania (Leishmania) mexicana in five foci of cutaneous leishmaniasis in the State of Campeche, México. Rev. Inst. Med. trop. S. Paulo, 51(2): 87-94, 2009.

30. IZOR, R.J. \& McCARTHY, T.J. - Heteromys gaumeri (Rodentia: Heteromyidae) in the northern plain of Belize. Mammalia, 48: 465-467, 1984.

31. JONES Jr., J.K.; GENOWAYS, H.H. \& LAWLOR, T.E. - Annotated checklist of mammals of the Yucatán Peninsula, Mexico. II. Rodentia. Occas. Pap. Museum Tex. Tech. Univ., 22: 1-24, 1974.

32. JONES Jr., J.K.; GENOWAYS, H.H. \& SMITH, J.D. - Annotated checklist of mammals of the Yucatan Peninsula, Mexico. III. Marsupialia, insectivora, primates, edentata, lagomorpha. Occas. Pap. Museum Tex. Tech. Univ., 23: 1-11, 1974.

33. KERR, S.F.; McHUGH, C.P. \& DRONEN Jr., N.O. - Leishmaniasis in Texas: prevalence and seasonal transmission of Leishmania mexicana in Neotoma micropus. Amer. J. trop. Med. Hyg., 53: 73-77, 1995

34. KERR, S.F.; McHUGH, C.P. \& MERKELZ, R. - Short report: a focus of Leishmania mexicana near Tucson, Arizona. Amer. J. trop. Med. Hyg., 61: 378-379, 1999.

35. LAINSON, R. - Cutaneous Leishmaniasis in Belize, Central America, and identity of the causative parasite. Trans. roy. Soc. trop. Med. Hyg., 78: 851-852, 1984.

36. LAINSON, R. \& SHAW, J.J. - Leishmaniasis in Brazil: III. Cutaneous Leishmaniasis in an opossum, Marmosa murina (Marsupialia, Didelphidae) from the lower Amazon region. Trans. roy. Soc. trop. Med. Hyg., 63: 738-740, 1969.

37. LAINSON, R. \& SHAW, J.J. - Leishmaniasis in Brazil. V. Studies on the epidemiology of cutaneous leishmaniasis in Mato Grosso State and observations on two distinct strains of Leishmania isolated from man and forest mammals. Trans. roy. Soc. trop. Med. Hyg., 64: 654-667, 1970.

38. LAINSON, R. \& STRANGWAYS-DIXON, J. - Dermal leishmaniasis in British Honduras: some host-reservoirs of Leishmania braziliensis mexicana. Brit. med. J., 1: 1596$1598,1962$.
39. LAINSON, R. \& STRANGWAYS-DIXON, J. - The epidemiology of dermal leishmaniasis in British Honduras: Part II. Reservoir-hosts of Leishmania mexicana among the forest rodents. Trans. roy. Soc. trop. Med. Hyg., 58: 136-153, 1964

40. LLANOS-CUENTAS, E.A.; RONCAL, N.; VILLASECA, P. et al. - Natural infections of Leishmania peruviana in animals in the Peruvian Andes. Trans. roy. Soc. trop. Med. Hyg., 93: 15-20, 1999.

41. McHUGH, C.P.; GROGL, M. \& KERR, S.F. - Isolation of Leishmania mexicana from Neotoma micropus collected in Texas. J. Parasit., 76: 741-742, 1990.

42. REBOLLAR-TÉLLEZ, E.A.; RAMÍREZ-FRAIRE, A. \& ANDRADE-NARVÁEZ, F.J - A two-years study on vectors of cutaneous leishmaniasis. Evidence for sylvatic transmission cycle in the state of Campeche, México. Mem. Inst. Oswaldo Cruz, 91: 555-560, 1996

43. VAN WYNSBERGHE, N.R.; CANTO-LARA, S.B.; DAMIÁN-CENTENO,A.G.; ITZÁORTIZ, M.F. \& ANDRADE-NARVÁEZ, F.J. - Retention of Leishmania (Leishmania) mexicana in naturally infected rodents from the State of Campeche, Mexico. Mem. Inst. Oswaldo Cruz, 95: 595-600, 2000

44. WIEGLE, K.A.; DE DÁVAlOS, M.; HEREDIA, P. et al. - Diagnosis of cutaneous and mucocutaneous leishmaniasis in Colombia: a comparison of seven methods. Amer J. trop. Med. Hyg., 36: 489-496, 1987.

45. WORLD HEALTH ORGANIZATION - Control of the Leishmaniases. Wld HIth Org. tech. Rep. Ser., (794), 1990

46. ZAVALA-VELÁZQUEZ, J. - Leishmaniasis in Yucatán. Gaceta med. Méx., 104: 1-9, 1972

Received: 21 March 2008

Accepted: 13 January 2009 